\title{
Comparative Study on Antimicrobial Activity of Four Bangladeshi Medicinal Plants Used as Antimicrobial Finishes on Cotton Fabric
}

\author{
Md. Ashraf ${ }^{1 *}$, Md. Hadisur Rahman ${ }^{1}$ and Mustafijur Rahman ${ }^{2}$ \\ ${ }^{1}$ Department of Wet Process Engineering, Bangladesh University of Textiles, Bangladesh \\ ${ }^{2}$ Department of Dyes and Chemicals Engineering, Bangladesh University of Textiles, Bangladesh
}

*Corresponding author: Md. Ashraf, Department of Wet Process Engineering,

Bangladesh University of Textiles, Dhaka, Bangladesh.

Received Date: February 16, 2021

Published Date: May 12, 2021

\begin{abstract}
Considering the post COVID19 pandemic situation, it can be assumed that using safer clothing will be a great attraction point for consumers across the world. In that scenario, effective antimicrobial finishes that are readily available and cheap would contribute to the consumer demand of safer clothing. This study scrutinized the antimicrobial activity of bleached cotton fabric treated with extracts of Ocimum tenuiflorum (Basil), Mentha spicata (Spearmint), Centella asiatica (Indian pennywort) and Azadirachta indica (Neem) as antimicrobial finishes. The study aims at assessing the comparative activity of four abovementioned natural medicinal plants which can be used as ecofriendly antimicrobial finishes for textiles. Bleached cotton fabric samples were treated with plant extractions following exhaust method and then evaluated by using ASTM E2149-01 method against gram positive bacteria Staphylococcus aureus and gram-negative bacteria Escherichia coli. The results depicted that all the four samples showed antimicrobial activity with more than $95 \%$ reduction of micro-organisms. Among the four, Ocimum tenuiflorum (Basil) showed the best result against both E. coli and S. aureus with reduction percentage of $98.81 \%$ and $99.16 \%$ respectively. Although Azadirachta indica (Neem) has comparatively the lowest performance against $E$. coli, its antimicrobial activity against $S$. aureus is very close to Ocimum tenuiflorum (Basil).
\end{abstract}

Keywords: Antimicrobial finish; Antimicrobial activity; Safer clothing; Cotton fabric; Basil; Spearmint; Indian pennywort; Neem; Bangladeshi medicinal plants

\section{Introduction}

Antimicrobial finish is an overwhelming area in the field of medical textile. It has significant technical and commercial applications in healthcare. The operation which is done to improve the appearance and usefulness of the textile fabric is generally known as textile finishing. Among two types of textile finishing, mechanical and chemical, antimicrobial finishing can be counted in chemical finishing. Antimicrobial finish can change fabric's several properties, for instance aesthetic properties, physical properties, texture and appearance [1]. The application of natural antimicrobial finishes to textiles can protect the human body from microbes. Microbes are undetected in naked eyes as they are tiniest in nature. They include variety of micro-organism e. g bacteria, fungi, algae and virus [2]. Among two types of bacteria, gram positive bacteria such as Staphylococcus aureus are mainly responsible for wound infection, toxic shock, osteomyelitis and other diseases. Nonetheless, the gram-negative bacteria Escherichia coli causes several infection diseases [3]. Human body comes in contact with microbes while performing their daily activities such as human body create perspiration and odor, which contain pathogenic microbes. These microbes are responsible for degradation and discoloration of garments [4]. Moreover, Perspiration contains salts, amino acids, carboxylic acids and other nutrients which can degrade textile materials and become a good source of microbial growth. The agents that work against the microbes are known as antimicrobial agents, 
which inhibit the growth or kill microbes to control their negative effect, most of which are biocides [5].

There are two types of antimicrobial finishes used as textiles finishes, for instances synthetic antimicrobial finish (organic and inorganic) and natural antimicrobial finish [6,7]. The synthetic antimicrobial agents are $\mathrm{ZnO}$ nanoparticles, quaternary ammonium salts, chloro-ether phenols, poly (hexamethylene bi-guanidine), silver and its compounds, organic-silicones, metal oxides, N-halamines, etc. But some synthetic antimicrobial agents are poisonous and can cause some illness such as skin irritation and hard to decompose in down streaming. That's why some are not allowed in some countries in the world [8].

On the other hand, natural antimicrobial agents are eco-friendly and health hygienic. Most of them are plant extraction. Among $4,00,000$ plant species on the earth, very few of them have been scrutinized for their antimicrobial activities. According to World Health Organization (WHO) $80 \%$ of the individual in developed countries use medicinal plants extraction as traditional medicine [9]. In USA, about $25 \%$ of prescription drugs contain at least one active ingredient derived from plant material [10]. Infectious diseases are most common in the world, and about 57 million people die of microbes. In Africa and Ghana, people for their health needs depend on traditional medicines due to the high cost of orthodox medicines, inadequate health facilities and healthcare professionals. They use medicinal plants for their skin disorders and for wound healing $[11,12]$. Concerning a safe milieu, the use of natural agents to functionalize textiles has attracted increasing attention. The potential use of different medicinal plants such as Nelumbo nucifera, Aloe vera, Trema guineensis, Phyllanthus discoideus, Acalypha wilkesiana, Berberis vulgaris, Cassia angustifolia, Cinnamomum cassia, Azadiracta indica, Acacia nilotica and Witania somnifera, Anabasis articulate, Chitosan, Azadirachta indica, Ocimum tenuiflorum, Punica granatum, Curcuma longa and other plants has been investigated in several parts of the world [13-16]. In Bangladesh, the antimicrobial activity of some medicinal plants (Psidium guajava, Terminalia arjuna, Phyllanthus embelica, Terminalia chebula, Justicia adhatoda, and Ocimum sanctum) has also been tested, used by indigenous community called Rakhaing [17].

Although Neem oil and Basil have been tested together in India [18], there were no reports on the comparative use of Ocimum tenuiflorum (Basil), Mentha spicata (Spearmint), Centella asiatica (Indian pennywort), Azadirachta indica (Neem) as textile finish, and no comparative analysis on their antimicrobial activities against Staphylococcus aureus and Escherichia coli bacteria. These are four Bangladeshi plants, which are available in every parts of the country, and are cost effective.

The objective of the present work is to assess the natural antimicrobial textile finishes extracted from Ocimum tenuiflorum (Basil), Mentha spicata (Spearmint), Centella asiatica (Indian pennywort), Azadirachta indica (Neem), and a comparative analysis of their antimicrobial activity.

\section{Experimental}

\section{Plant materials}

Ocimum tenuiflorum (Basil), Mentha spicata (Spearmint), Centella asiatica (Indian pennywort) were collected from Savar, Dhaka, Bangladesh and Azadirachta indica (Neem) were collected from Bangladesh university of Textiles campus, Dhaka, Bangladesh.

\section{Plant extraction}

Collected leaves of selected plants were cleaned, sun dried and then dried by an oven at $60^{\circ} \mathrm{C}$. Dried leaves then grinded and made into the powder form. It consumed total 5 hours from collection to grinding the plant leaves. $20 \mathrm{~g}$ of grinded powders from each type of plants were mixed with $100 \mathrm{ml}$ of absolute methanol. These mixtures were kept for 24 hours prior to the filtration of mixtures. Filtrated mixtures were used to give antimicrobial finish on the cotton fabric.

\section{Selection of fabric}

$40 \mathrm{Ne}$ count $100 \%$ cotton yarn was woven at the fabric laboratory of Bangladesh University of Textiles.1/1 Plain weave was chosen as the fabric structure. Sample size was $5 \mathrm{~cm} \times 5 \mathrm{~cm}$.

\section{Pretreatment of fabric}

Pretreatment of the fabric was done with a solution containing caustic soda (30 g/l), detergent ( $5 \mathrm{~g} / \mathrm{l})$, wetting agent $(3 \mathrm{~g} / \mathrm{l})$ and sequestering agent $(2 \mathrm{~g} / \mathrm{l})$.

\section{Sample preparation: Exhaust method}

Filtrated mixtures were mixed with 1:20 ratio and treated with sample fabrics in four different beakers for 2 hours at $60{ }^{\circ} \mathrm{C}$. The treated samples were cured in room temperature and dried in covered plates. Thus, finishing was done, and the samples got prepared.

\section{Antimicrobial activity testing}

Antimicrobial property of cotton fabric samples that were treated with Ocimum tenuiflorum (Basil), Mentha spicata (Spearmint), Centella asiatica (Indian pennywort) and Azadirachta indica (Neem) were tested by using ASTM E2149-01 [19]. This is a quantitative antimicrobial test method that can evaluate the resistance of non-leaching antimicrobial treated specimens to the growth of the microbes under dynamic contact conditions. Antimicrobial activity testing was done against gram-positive bacteria (Staphylococcus aureus) and gram-negative bacteria (Escherichia coli) in the microbiology lab of Primeasia University, Dhaka, Bangladesh.

Each culture was suspended in a small amount of nutrient broth, spread on the nutrient agar plate, and incubated at $37{ }^{\circ} \mathrm{C}$ for 2 hours. Two single colonies were picked up with an inoculating loop from the agar plate, suspended in $5 \mathrm{ml}$ nutrient broth, and incubated for 18 hours at $37^{\circ} \mathrm{C}$. A final concentration of 1.5 $3.0 \times 105$ colony forming units per milliliter $(\mathrm{CFU} / \mathrm{ml})$ was prepared by appropriately diluting each culture with a steric buffer solution $(0.3 \mathrm{mM}$ phosphate buffer, $\mathrm{pH} 7.2)$ which was used as diluent in all 
experiments. These dilute culture solutions were used for the antimicrobial test.

For each type of treated and untreated sample, a $250 \mathrm{ml}$ flask was prepared containing $50 \mathrm{ml}$ of the working bacterial dilution (1.5-3.0×105 CFU/ml) and fabric samples which were cut into small pieces $(4.8 \mathrm{~cm} \times 4.8 \mathrm{~cm})$. All flasks were capped loosely, placed on a shaking incubator, were shaken at $37{ }^{\circ} \mathrm{C}$ and $120 \mathrm{rpm}$ for 1 hour. A series of dilutions were made using the buffer solution and each $0.1 \mathrm{ml}$ of the dilution was placed in nutrient agar plate. The inoculated plates were incubated by incubator (Binder from USA) at $37^{\circ} \mathrm{C}$ for 24 hours and surviving cells were counted. Safety cabinet (Clernair from Belgium) was used to carry out the preparation of bacteria culture and transferring to agar plate [20].

The antimicrobial activity was assessed and compared using the following equation:

$$
\% \operatorname{Re} \text { duction }=\frac{B-A}{B} \mathrm{X} 100
$$

Where $\mathrm{A}$ is the number of surviving cells (CFU/ml) for the flasks containing test samples and B is the number of surviving cells ( $\mathrm{CFU} / \mathrm{ml}$ ) for the flasks containing the control samples after onehour contact time for both. \% Reduction expresses the percentages of bacteria that were killed by the antimicrobial finishes that were applied on the cotton fabric.

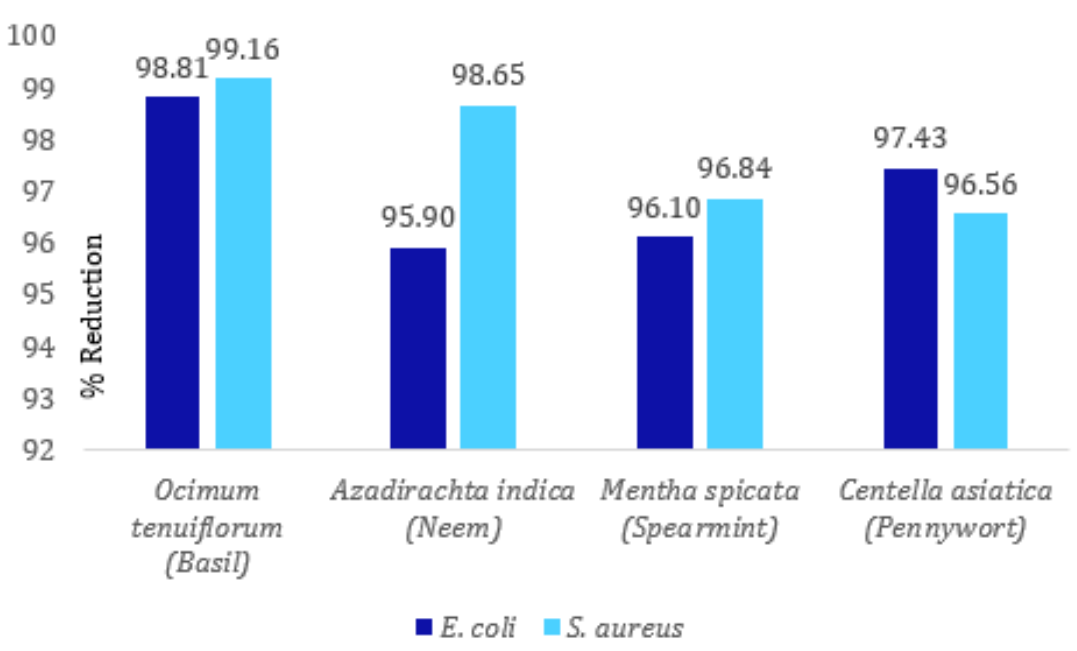

Figure 1: Reduction percentages against E.coli and S. aureus.

Table 1: Surviving cells of bacteria on control and sample fabric.

\begin{tabular}{|c|c|c|c|c|}
\hline \multirow{2}{*}{ Name of Medicinal Plant } & \multicolumn{2}{|c|}{ E. coli $(\mathrm{CFU} / \mathrm{ml})$ Survived } & \multicolumn{2}{|c|}{ S. aureus $(\mathrm{CFU} / \mathrm{ml})$ Survived } \\
\hline & Control Fabric & Sample Fabric & Control Fabric & Sample Fabric \\
\hline Ocimum tenuiflorum (Basil) & \multirow[t]{4}{*}{$2.10 \times 10^{5}$} & $25 \times 10^{2}$ & \multirow[t]{4}{*}{$2.15 \times 10^{5}$} & $18 \times 10^{2}$ \\
\hline Azadirachta indica (Neem) & & $86 \times 10^{2}$ & & $29 \times 10^{2}$ \\
\hline Mentha spicata (Spearmint) & & $82 \times 10^{2}$ & & $68 \times 10^{2}$ \\
\hline Centella asiatica (Pennywort) & & $54 \times 10^{2}$ & & $74 \times 10^{2}$ \\
\hline
\end{tabular}

\section{Results and Discussion}

Results obtained from the test to assess the antimicrobial activity of four medicinal plants, have been demonstrated below in an understandable way to get the idea on the comparative antimicrobial activity of the tested plants. Table 1 shows the counts of surviving cells of E. coli and S. aureus bacteria for the control fabric and for Ocimum tenuiflorum (Basil), Azadirachta indica (Neem), Mentha spicata (Spearmint) and Centella asiatica (Pennywort) treated sample fabrics. Figure 1 shows the reduction percentages of bacteria for all four samples.
Result resembles that all the four samples showed excellent antimicrobial activity with more than $95 \%$ reduction of micro-organisms. Among the four, Ocimum tenuiflorum (Basil) showed the best result against both $E$. coli and $S$. aureus with reduction percentages of $98.81 \%$ and $99.16 \%$ respectively. Figure 2 displays the counts of Ocimum tenuiflorum (Basil) treated sample against both $E$. coli and S. aureus.

Kaya, et al. [21] examined the antimicrobial activity of various extracts (chloroform, acetone and methanol) of Ocimum tenuiflorum (Basil) and found best result using the methanol extract. Fur- 
thermore, they observed satisfactory antimicrobial activity against both gram-positive and gram-negative bacteria. Both of these findings correspond to this study. Lachowicz, et al [22] studied the antimicrobial activity from five oils of sweet Basil against 24 (13 gram-positive and 11 gram-negative) bacteria and observed notable activity against 20 bacteria, including significant activity against $E$. coli and S. aureus. They also found that Basil samples are more effective against gram-positive bacteria than gram-negative bacteria. This study presents the same as Ocimum tenuiflorum (Ba- sil) provides the greater reduction percentage (99.16\%) against gram-positive $S$. aureus compared to the reduction percentage (98.81\%) against gram-negative E. coli. In another study from Iran, Moghaddam, et al. [23] also observed the significant antimicrobial activity against both $E$. coli and $S$. aureus with a different species of Basil, named Ocimum basilicum. Dostalova, et al. [24] studied the antimicrobial activity of aqueous extract of Basil against gram-negative bacteria including $E$. coli and observed high potential to inhibit bacterial growth.
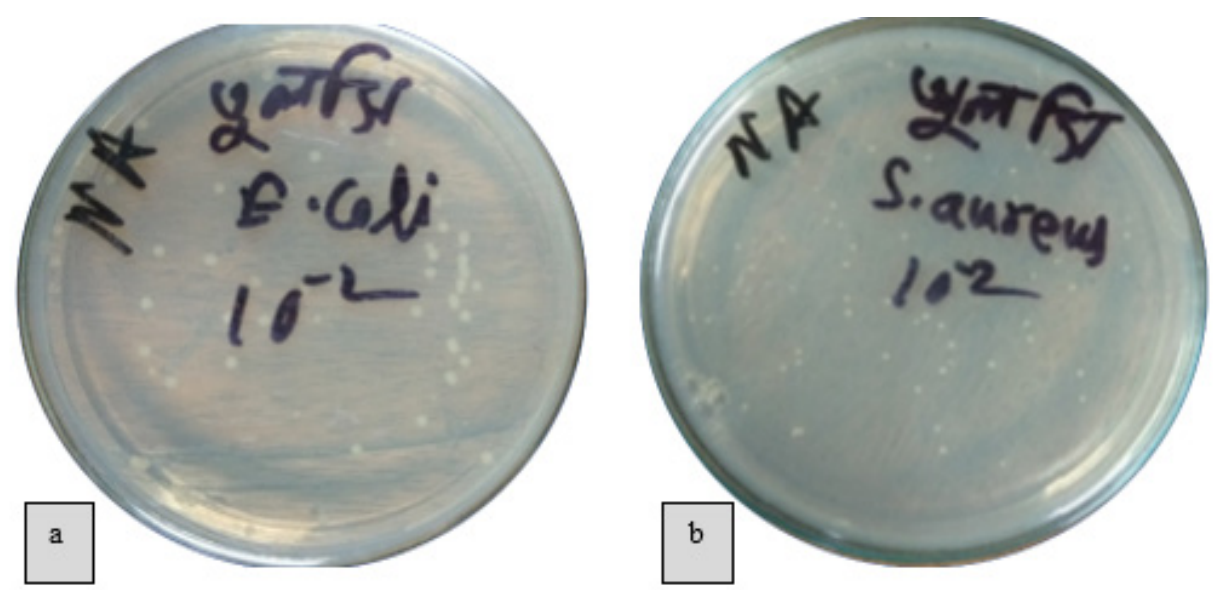

Figure 1: Counts of Ocimum tenuiflorum (Basil) treated sample against (a) E. coli and (b) S. aureus.

After Basil, Centella asiatica (Pennywort) provides the next best result comprising of $97.43 \%$ and $96.56 \%$ reduction against $E$. coli and $S$. aureus respectively. Figure 3 displays the counts of Centella asiatica (Pennywort) treated sample against both E. coli and S. aureus.
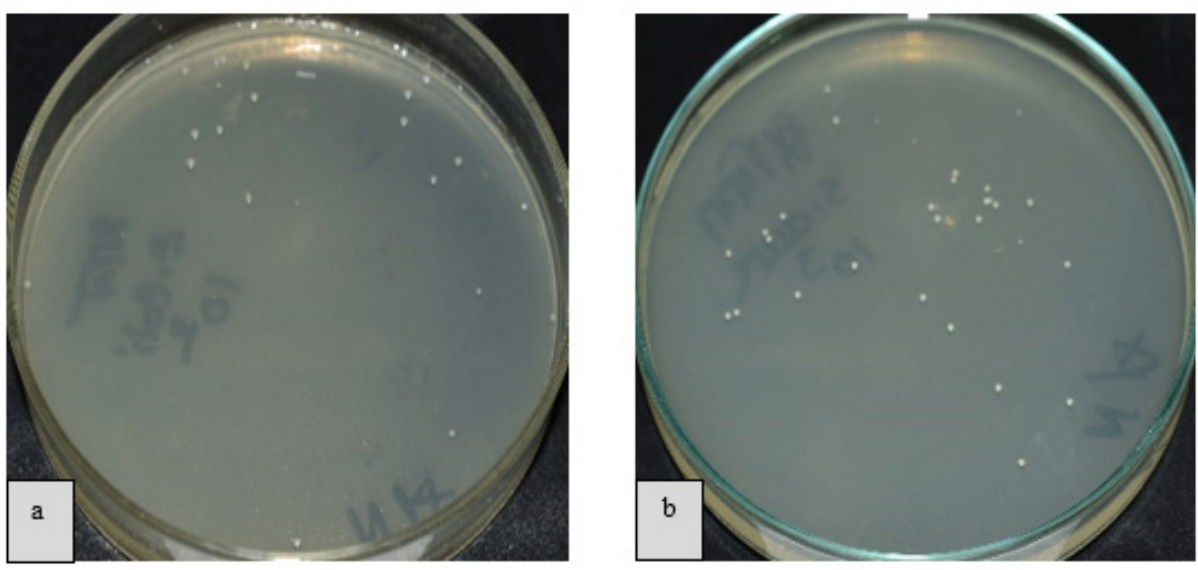

Figure 3: Counts of Centella asiatica (Pennywort) treated sample against (a) E. coli and (b) S. aureus.

Arumugam, et al. [25] tested the antimicrobial activity of Centella asiatica (Pennywort) and observed significant activity against E. coli and $S$. aureus. Their study found comparatively higher potential to inhibit the growth of $E$. coli than $S$. aureus. This study detected the similar result as the reduction percentage $(97.43 \%)$ against E. coli is higher than the reduction percentage (96.56\%) against $S$. aureus. Another study by Samy, et al. [26] spotted the similar an- timicrobial activity E. coli and S. aureus by the methanol extracts of Centella asiatica (Pennywort). Two more studies by Nasution, et al. [27] and Dash, et al. [28] found excellent antimicrobial activity of Centella asiatica (Pennywort) against E. coli and S. aureus, along with some other bacteria. But both of those used ethanol extract of Centella asiatica (Pennywort) whereas this study is based on methanol extracts.Although Azadirachta indica (Neem) has compara- 
tively the lowest performance against $E$. coli, it indicates impressive antimicrobial activity against $S$. aureus which is very close to the result of Ocimum tenuiflorum (Basil).

Maleki, et al. [29] noticed that methanol extract of Azadirachta indica (Neem) provides the strongest antimicrobial activity against $S$. aureus. Tirumalasetty et al also perceived methanol extracts to provide noteworthy antimicrobial activity against $E$. coli and $S$. aureus. Alike this study, their study also detected higher antimicrobial activity against $S$. aureus, compared to the activity against $E$. coli [30]. Mohammed et al. tested the methanol extract of Azadirachta indica (Neem) leaves against 6 bacterial species, including E. coli and $S$. aureus. Although they received strong antimicrobial activity against all the six bacterial species, antimicrobial activity was the lowest against $E$. coli, which is very similar to this study [31].

\section{Conclusion}

This study has given a comparative idea for the application of antimicrobial finishes on bleached cotton fabric using Ocimum tenuiflorum (Basil), Mentha spicata (Spearmint), Centella asiatica (Indian pennywort) and Azadirachta indica (Neem). Among these four plants, Ocimum tenuiflorum (Basil) exhibited excellent antimicrobial activity, which reduced almost $98-99 \%$ bacteria. Overall, the result indicates the potential of these plants to be used for antimicrobial textile products. As these plants are locally very easily collectible and very cheap, further extensive study can confirm the feasibility of commercial use of these plants as antimicrobial agent.

The study has the further scope to continue by testing the antimicrobial activity after washing the fabric sample to measure the durability of used finishes against washing and measure the number of washes up to which the antimicrobial activity remains effective. Also testing the strength, color fastness and dimensional stability shall give a precise idea on the fabric quality after antimicrobial treatment.

Considering the consumer demand of safer clothing as an effect of COVID19 pandemic, the application of locally extracted and cheap medicinal plants to produce antimicrobial fabrics is supposed to be highly efficient and cost-effective.

\section{Acknowledgement}

None.

\section{Conflict of Interest}

Authors declare no conflict of interest.

\section{References}

1. Hehlen M (1979) Fabric finishing.

2. Ayyoob M, Khurshid MF, Asad M, Shah SNH (2015) Assessment of ecofriendly natural antimicrobial textile finish extracted from aloe vera and neem plants. Fibres Text East Eur 23(6): 120-123.

3. Zwetlana A, Nandini M, Dorcas K (2014) Antimicrobial activity of medicinal plant extracts on gram negative bacteria. 2(5): 51-54.

4. Oh KW, Na YJ (2014) Antimicrobial activity of cotton fabric treated with extracts from the lotus plant. Text Res J 84(15): 1650-1660.
5. Shalini D, Anitha G (2016) A Review: Antimicrobial Property of Textiles. Int J Sci Res 5(10): 766-768.

6. Singh G, Joyce EM, Beddow J, Mason TJ (2012) Evaluation of Antibacterial Activity of ZnO Nanoparticles. J Microbiol Biotechnol Food Sci 2(1): 106120.

7. Naveed M (2018) Performance on Antibacterial Finishes for Textile Applications. Trends Text Eng Fash Technol 2(5): 226-235.

8. Babu KM (2003) Antimicrobial finishes for textiles. Asian Text J 12(4): 64-68.

9. Ramadas V, Shibila Selva Kishore S (2012) Antimicrobial activity of selected medicinal plants against some selected human pathogenic bacteria. Pelagia Res Libr Adv Appl Sci Res 3(5): 3374-3381.

10. Abere TA, Okoto PE, Agoreyo FO (2010) Antidiarrhoea and toxicological evaluation of the leaf extract of Dissotis rotundifolia triana (Melastomataceae). BMC Complement Altern Med 10: 71.

11. Agyare C, Asase A, Lechtenberg M, Niehues M, Deters A, et al. (2009) An ethnopharmacological survey and in vitro confirmation of ethnopharmacological use of medicinal plants used for wound healing in Bosomtwi-Atwima-Kwanwoma area, Ghana. J Ethnopharmacol 125(3): 393-403.

12. Akhtar N, Ihsan-ul-Haq, Mirza B (2018) Phytochemical analysis and comprehensive evaluation of antimicrobial and antioxidant properties of 61 medicinal plant species. Arab J Chem 11(8): 1223-1235.

13. Akinyemi KO, Oluwa OK, Omomigbehin EO (2006) Antimicrobial activity of crude extracts of the three medicinal plants used in South-West Nigerian folk medicine on some food borne bacterial pathogens. African J Tradit Complement Altern Med 3(4): 13-22.

14. Bereksi MS, Hassaïne H, Bekhechi C, Abdelouahid DE (2018) Evaluation of antibacterial activity of some medicinal plants extracts commonly used in algerian traditional medicine against some pathogenic bacteria. Pharmacogn J 10(3): 507-512.

15. Kumar A, Jhadwal N, Lal M, Singh M (2012) Antibacterial activity of some medicinal plants used against UTI causing pathogens. Int J Drug Dev Res 4(2): 278-283.

16. Sahraei S, Mohkami Z, Golshani F, Javadian F, Saeidi S, et al. (2014) Antibacterial activity of five medicinal plant extracts against some human bacteria. Pelagia Res Libr Eur J Exp Biol 4(3): 194-196.

17. (2014) Antibacterial activity of some selected medicinal plants used by the Rakhaing community of Cox 's Bazar district of Bangladesh. Acad J Microbiol Res 2: 21-27.

18. Malpani SR (2013) Antibacterial Treatment on Cotton Fabric from Neem Oil, Aloe Vera \&Tulsi. Int J Adv Res Sci Eng 8354(2): 35-43.

19. Varesano A, Vineis C, Aluigi A, Rombaldoni F (2011) Antimicrobial polymers for textile products. Sci Against Microb Pathog 1: 99-110.

20. Hassan Shibly MM, Hossain MF, Rahman M, Nur G (2019) Development of Cost-Effective Menstrual Absorbent Pad with Eco-Friendly Antimicrobial Finish. Eur Sci J 15: 36.

21. Kaya I, Yigit N, Benli M (2008) Antimicrobial activity of various extracts of Ocimum basilicum l. and observation of the inhibition effect on bacterial cells by use of scanning electron microscopy. African J Tradit Complement Altern Med 5 4): 363.

22. Lachowicz KJ, Jones GP, Briggs DR, Bienvenu FE, Wan J, et al. (1998) The synergistic preservative effects of the essential oils of sweet basil (Ocimum basilicum L) against acid-tolerant food microflora. Lett Appl Microbiol 26(3): 209-214.

23. Moghaddam AMD, Shayegh J, Mikaili P, Sharaf JD (2011) Antimicrobial activity of essential oil extract of Ocimum basilicum L. leaves on a variety of pathogenic bacteria. J Med Plants Res 5(15): 3453-3456.

24. Dostalova L, Detvanoca L, Kalhotka L (2014) Antimicrobial activity of aqueous herbal extracts. Mendel Net: 403-406.

25. Arumugam T, Ayyanar M, Koil Pillai YJ, Sekar T (2011) Phytochemical screening and antibacterial activity of leaf and callus extracts of Centella asiatica. Bangladesh J Pharmacol 6(1): 55-60. 
26. Perumal Samy R, TK Chow V (2011) Antimicrobial and Phytochemical Analysis of Centella asiatica (L.). Nat Preced.

27. Nasution MY, Restuati M, Pulungan ASS, Pratiwi N, Diningrat DS (2018) Antimicrobial activities of Centella asiatica leaf and root extracts on selected pathogenic micro-organisms. J Med Sci 18(4): 198-204.

28. Dash BK, Faruquee HM, Biswas SK, Alam MK, Sisir SM, et al. (2011) Antibacterial and Antifungal Activities of Several Extracts of Centella asiatica L. against Some Human Pathogenic Microbes," Life Sci. Med. Res., vol. 2011, no. 1, p. 35, 2011.

29. Maleki L, Sadeghian-Rizi T, Ghannadian M, Sanati MH, Shafizadegan S, et al. (2017) Antibacterial Activity of Azadirachta indica Leaf Extracts
Against Some Pathogenic Standards and Clinical Bacterial Isolates. Avicenna J Clin Microbiol Infect 5(1): 8-13.

30. Tirumalasetty J, Basavaraju A, Praveena (2014) Antimicrobial activity of methanolic extracts of Azadirachta indica, Rosmarinus officinalis and Lagenaria siceraria leaves on some important pathogenic organisms. J Chem Pharm Res 6(4): 766-770.

31. Mohammed HA, Fadhil A, Omer A (2015) Antibacterial Activity of Azadirachta indica (Neem) Leaf Extract against Bacterial Pathogens in Sudan. Am J Res Commun 3(5): 246-251. 